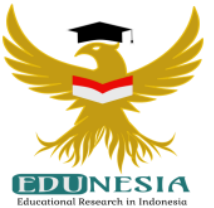

\title{
Increasing Activities and Learning Outcomes of Class X MIPA-1 SMAN 1 Danau Panggang through Collaboration of 3 Kinds of Discussion Instruments with Animated Product Assignments
}

\author{
Noraini \\ Biology Education, SMAN 1 Danau Panggang Kab. HSU Kalimantan Selatan, Indonesia \\ Corresponding Email: norainihsu3@gmail.com, Phone Number : 0812 xxxx xxxx
}

Article History:

Received: Apr 19, 2021

Revised: May 12, 2021

Accepted: May 22, 2021

Online First: Jun 01, 2021

\section{Keywords:}

Activities, Animation,

Instruments, Learning

Outcomes, Plantae.

Kata Kunci:

Aktivitas, Animasi, Hasil

Belajar, Instrument, Plantae.

\section{How to cite:}

Noraini, N. (2021). Increasing Activities and Learning Outcomes of Class X MIPA-1 SMAN 1 Danau Panggang through Collaboration of 3 Kinds of Discussion Instruments with Animated Product Assignments. Edunesia: Jurnal Ilmiah Pendidikan, 2 (2): 527-533.

This is an open access article under the $C C$-BY-NC-ND license

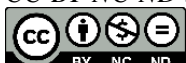

\begin{abstract}
: low activity and student learning outcomes in a class are influenced by several factors, one of which is because the behavior and learning models used by the teacher are not yet correct in implementing a learning process. These problems can affect the activity and completeness of student learning outcomes, so there needs to be special instruments that make them more active, especially on the subject of biology which contains many scientific names such as on the subject of Plantae. The purpose of this study was to determine the collaboration of three discussion instruments with the task of learning media products in the form of power points to increase student activity and student learning outcomes of class X MIPA-1 on the subject of Plantae. This research method uses comparative descriptive analysis with a qualitative approach using simple formulas in the form of calculating averages and percentages. The results of this study indicate that the class average score is 83.64 with the completeness of learning outcomes $90.91 \%$ with this value the completeness criteria can be categorized as achieved with student activity increasing from $73.21 \%$ to $96.63 \%$ with the criteria categorized as very good.
\end{abstract}

Abstrak: rendahnya aktivitas dan hasil belajar siswa dalam sebuah kelas dipengaruhi oleh beberapa faktor, salah satunya adalah karena tingkah laku dan model pembelajaran yang digunakan oleh guru belum tepat dalam pelaksanaan sebuah proses pembelajaran. Masalah tersebut dapat mempengaruhi aktivitas dan ketuntasan hasil belajar siswa, sehingga perlu adanya instrumen khusus yang membuat mereka lebih aktif, utamanya pada pokok bahasan biologi yang banyak memuat banyak nama ilmiah seperti pada pokok bahasan Plantae. Tujuan penelitian ini adalah ingin mengetahui kolaborasi tiga instrumen diskusi dengan tugas produk media pembelajaran berupa power point dapat meningkatkan aktivitas siswa dan hasil belajar siswa kelas X MIPA1 pada pokok bahasan Plantae. Metode penelitian ini mengunakan analisis diskriptif komperatif dengan pendekatan kualitatif menggunakan rumus-rumus sederhana berupa perhitungan ratarata dan persentase. Hasil penelitian ini menunjukan bahwa nilai rata-rata kelas adalah 83,64 dengan ketuntasan hasil belajar 90,91\% dengan nilai tersebut kreteria ketuntasan dapat dikatagorikan tercapai dengan aktivitas siswa meningkat dari 73,21\% menjadi $96.63 \%$ dengan kreteria dikategorikan sangat baik. 


\section{A. Introduction}

According to the Biological Science Curriculum Study (BSCS) biology includes 9 basic themes, namely Biology (science) as an inquiry process, history of the biology's concept, evolution, diversity and uniformity, genetics and survival, organisms and the environment, behavior (ethology), structure and function, and regulation. However, in line with the development of science. Biological objects and problems continue to develop through scientific research in Biology (Grobman, 2018; Anderson, 2013; Santoso et al, 2017).

According to Tammu (2018), Biology is a branch of knowledge that deals with living organisms and vital processes. Meanwhile, according to Fitriah (2016), Biology is a part of science that emphasizes giving direct experience. Therefore, students need to be helped to develop a number of skills so that they are able to explore and understand their surroundings and themselves.

There are many benefits in studying Biology for human life, including as described by Ariwidodo (2020), namely to reveal the secrets of life processes, inheritance, and genes so that they can be used to change the traits in agricultural plants to become superior and produce many hybrid plants with fixed properties.

Biology topics related to plants or plants are plantae. This subject is studied in class $X$ semester II. In this subject almost every year students have difficulty understanding it. In the pre-cycle the last learning outcome got an average score of 62.35 in the low category, even though the classical completeness criteria was 70. This happened because the Biology discussion partially contained scientific names or Biological languages which were quite complicated and difficult. Certain methods and models have been applied to improve student learning outcomes, but the results are not as expected. In connection with this problem, it is necessary to have supporting learning media coupled with discussion instruments that will be used in order to increase activities and learning outcomes of Biology.

Before using learning media and discussion instruments in this study, preliminary trials and validation of their use had been carried out. Testing and validation is carried out in other classes which are equivalent to good results. The learning media that will be used in this study are appropriate and have practical value, as said by Alwi (2017), that the practical values of learning media can lay real foundations for thinking, because they reduce verbalism, the media can increase interest and attention. students to learn and the media can lay the foundation for learning development so that learning outcomes grow steadily. Basically, learning media and interest in learning are closely related to the learning process.

While the discussion instrument made in this study is in accordance with the principles of its manufacture and is relevant, as said by Fadillah (2017), one of the characteristics of a good instrument is relevant. Relevant means that the instrument used must match the material being taught with the context of assessing learning outcomes. Assessment activities carried out by the teacher can be done in various ways, one of which is in the form of a paper and pencil test. However, the paper and pencil tests used by the teacher only measured cognitive abilities and paid less attention to assessing students' processing skills.

Based on observations made prior to conducting this research, most teachers paid less attention to the assessment of process skills, only asking their students to present the results of their discussions through advancing together in front of the class, it could also be just group discussions each or in groups rewriting the material. on the blackboard, so that it seems not serious like playing games, looks monotonous, boring, most of them seem not 
actively listening to the material presented, actively listening to questions, not actively listening to answers in an ongoing discussion and the process of learning activities teaching them also seems conventional, not in accordance with their current digital age. The low activity and student learning outcomes in a class are influenced by many things, including because the behavior and learning models used by the teacher are not yet correct in implementing a learning process. These problems, among others, can affect the activities and completeness of student learning outcomes, so there is a need for learning media and special discussion instruments that make them more active, especially on the subject of Biology which contains many scientific names such as on the subject of Plantae.

Problems with low student learning activities and outcomes need to be resolved immediately. One of the efforts made is facilitating a discussion through 3 kinds of discussion instruments that are collaborated with the task of learning media products in the form of power points.

\section{B. Method}

The research design used is Classroom Action Research (CAR) which aims to increase student activity and learning outcomes through collaboration of 3 discussion instruments with power point animation learning media product assignments. The number of students who will be the subjects is 22 students of class X MIPA-1 SMAN 1 Danau Panggang consisting of 8 men and 14 women. In this study, the object of research is an indicator of the success of the action in the form of psychomotor and cognitive assessments. Psychomotor assessment in the form of powerpoint product results with the category of assessment 80-100 very successful, 60-79 successful, 40-59 enough, 20-39 less successful, 019 unsuccessful. Cognitive assessment in the form of minimum completeness criteria, namely 75-100 successful and 0-74 unsuccessful.

The place of this research is SMAN 1 Danau Panggang, Jl Sukaramai RT.04, No.63 Danau Panggang District. Research time was January 2020 - June 2020. The number of students to be studied was 22 students of class X MIPA-1 SMAN 1 Danau Panggang consisting of 8 men and 14 women.

The stages of this research consisted of 2 cycles, each of which the detailed steps were the same, namely planning, implementing, observing and reflecting. The data collection technique in this study was through written posttests which were used to measure cognitive abilities or student learning outcomes. Student activity observation sheets and three discussion instruments.

Analysis of the data to determine the activities and student learning outcomes using a descriptive comparative analysis with a qualitative approach in the form of calculations using the following formulas.

$$
\%=\frac{\mathrm{n}}{\mathrm{N}} \times 100
$$

Note:

$\mathrm{n} \quad=$ The number of students who scored $\geq 65$

$\mathrm{N} \quad=$ The total number of students

Value $<65$ = students did not complete their studies

Value $\geq 65=$ students complete their studies

(Muhidin \& Abdurahman, 2011). 
Calculate the class average value with the formula:

Note:

$\mathrm{X} \quad=$ Average $($ mean $)$

$$
\overline{\mathrm{X}}=\frac{\sum X}{N}
$$

$\sum \mathrm{X}=$ sum of all scores

$\mathrm{N} \quad=$ number of subjects

Sudjana (2010).

The results of the student activity observation sheet were analyzed in the following way:

$$
\mathrm{NP}=\frac{\mathrm{R}}{\mathrm{SM}} \times 100
$$

Note:

$\mathrm{NP} \quad=$ Percent value sought

$\mathrm{R} \quad=$ score obtained by students

$\mathrm{SM} \quad=$ ideal maximum score

$100=$ Fixed number

This success indicator includes the percentage of student learning outcomes, and student activities. Learning outcomes are said to be successful if they meet the completeness percentage $\geq 65 \%$. Student activity is said to be successful if it meets the percentage of $50 \%$ $<x \leq 75 \%=$ Good or $75 \%<x \leq 100 \%=$ Very Good (Purwanto, 2010).

\section{Result and Discussion}

The value of student learning outcomes in all cycles can be seen in table 1 below:

Table 1. The value of student learning outcomes in pre-cycle, cycle I and cycle II

\begin{tabular}{cccc}
\hline Category & $\begin{array}{c}\text { Pre-cycle } \\
\text { Value }\end{array}$ & $\begin{array}{c}\text { Cycle I } \\
\text { Value }\end{array}$ & $\begin{array}{c}\text { Cycle II } \\
\text { Value }\end{array}$ \\
\hline Average & 62.73 & 76.36 & 83.64 \\
Completeness & $36.36 \%$ & $68.18 \%$ & $90.91 \%$ \\
\hline
\end{tabular}

Furthermore, observations were made to see the increase in student activity in each cycle as in table 2 below.

Table 2. Results of observation of student activities in cycle I and II

\begin{tabular}{ccc}
\hline Category & $\begin{array}{c}\text { Cycle I } \\
\text { Value }\end{array}$ & $\begin{array}{c}\text { Cycle II } \\
\text { Value }\end{array}$ \\
\hline Total & 41 & 54 \\
Student activity $(\%)$ & 73.21 & 96.43 \\
\hline
\end{tabular}

The value of learning outcomes and observations of student activities in each cycle can be seen in Figure 1 below: 


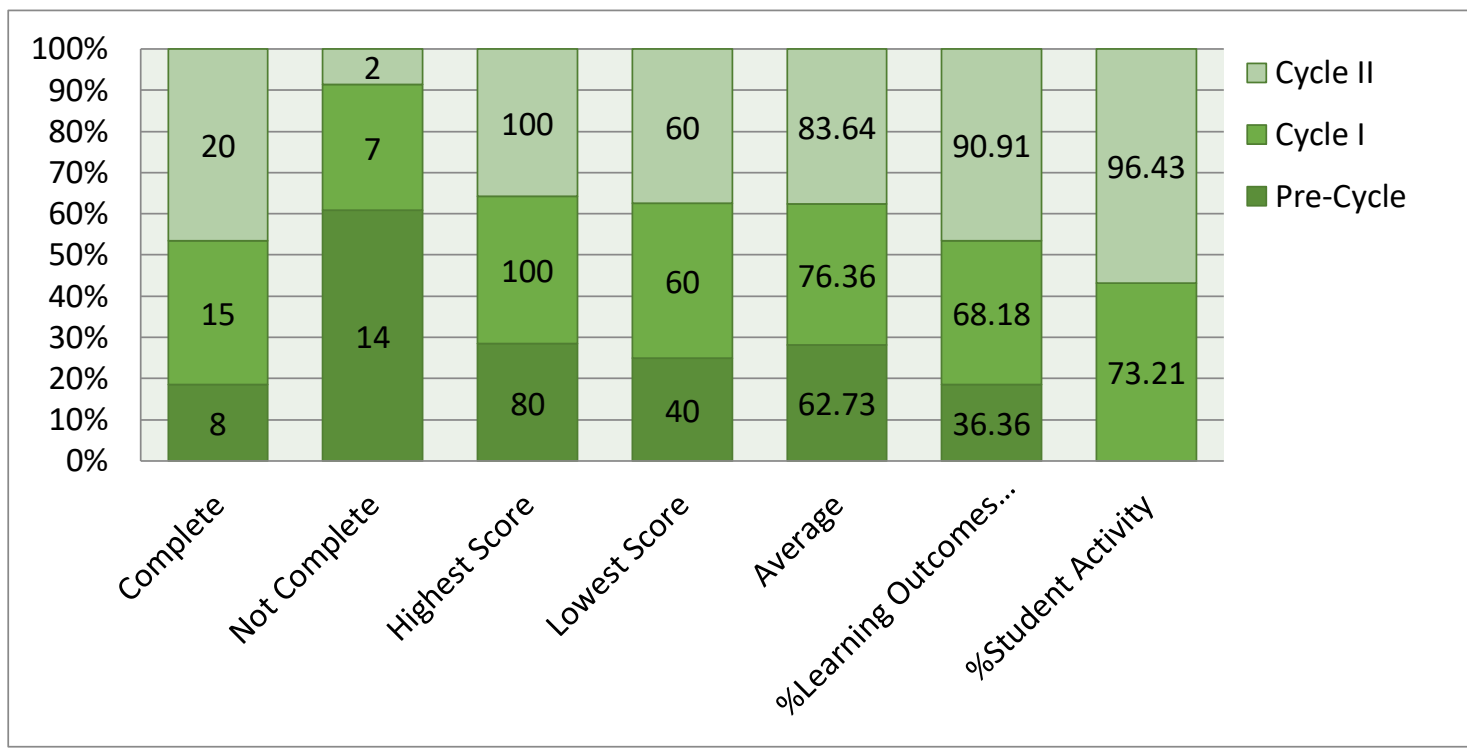

Figure 1. Measurement of Student Learning Outcomes and Activities.

The average value increased to 62.73 in cycle I to 76.36 and increased in cycle II to 83.64. The lowest value in pre-cycle is 40 , but in cycle II it increases to 60 . The highest value of the pre-cycle increased from 80 to 100 in the second cycle. Students who completed also increased from 8 pre-cycle to 20 in cycle II. Meanwhile, student activities also increased from $73.21 \%$ to $96.43 \%$ with the criteria being categorized from good to very good.

Based on the summary of the value data in tables 1 and 2, from the pre-cycle it was obtained the average value of 62.73 increased to 76.36 in cycle I. The initial lowest value was 40 , increasing to 60 . Meanwhile, the highest score also increased, which initially increased to 80 to 100 . Students who completed the first cycle increased from 8 to 15 people. But to find out or ascertain whether because this student activity has indeed increased due to the collaboration of three discussion instruments with the task of power point animation learning media products, it is necessary to continue in cycle II.

Based on the summary value data in table 2, from cycle II the average value is 83.64 with $90.91 \%$ completeness of learning outcomes. The number of students who completed was 20 people and only 2 did not complete, the lowest score was 80 and the highest was 100 . In this cycle II activity, completeness of learning outcomes has reached $>65 \%$, so there is no need to take cycle III actions.

Based on the summary of the student activity observation data in the first cycle the value was $73.21 \%$. This value when compared with the criteria indicator, namely $50 \%<x \leq$ $75 \%$, is categorized as good. While the results of observations of student activities in cycle II obtained a value of $96.43 \%$. This value when compared with the criteria indicator, which is $75 \%<x \leq 100 \%$, is categorized as very good.

Based on the facts in the process of teaching and learning activities that researchers do in a action research or outside of a action research, this student activity increases as a result of the collaboration of three discussion instruments with the task of power point animation products so that it becomes a cooperative and fun learning model because students can visualize. words, sentences, videos and pictures all at once so that it raises curiosity to make a question. 
According to Sabri (2013) in the learning process, asking questions is a technique to facilitate the process of understanding the material being studied and can improve thinking skills. Talking about the role of asking, it cannot be separated from the function of the question itself. Teaching does not only instill concepts or convey information to students but also trains students to gain the ability to think or solve problems on their own, because the learning process is obtained from the ability to think both through teaching and learning activities in class and when students learn on their own. So the teacher should try to get as many students as possible to participate in the teaching and learning process.

To increase the activity and student learning outcomes in the process of teaching and learning activities, among others, is done by collaborating the three discussion instruments with the power point animation product assignment.

Several studies that support and are relevant to the results of the above research include research conducted by Mayer and Anderson, Mousavi and Sweller and Novitasari. According to Mayer and Andreson (2010) researching animation instruction in teaching that can help students build relationships between words and images in multimedia learning, where the results show that students who get narrative explanations along with animation have higher scores than students who are given narration or amination.

The opinion of Mousavi et al (2010) examines the reduction of cognitive content by blending audio and visual presentation models. The results showed that various sources of information produce a large cognitive content, effective cognitive capacity can be increased when used audio and visuals.

According to Novitasari et al (2015) in the results of their research which aims to test the effectiveness of the Problem Based Learning (PBL) model assisted by audio-visual media on student motivation and learning outcomes. This study used an experimental design, using two classes as an experimental class and a control class. The population in this study were all students of class VIII SMP Negeri 1 Garung while the sample in this study was class VIII A (experimental class) using PBL model assisted by audiovisual media. and class VIII $\mathrm{B}$ (control class) using cooperative learning. Student learning motivation data were obtained through a questionnaire. Student knowledge competency learning outcomes data were taken from a written test of excretion system material, skills competencies were taken from observations, and attitudinal competencies from self-assessment questionnaires, peer to peer, and observations. The data analysis technique used is descriptive percentage and $t$ test. The results showed that the PBL model assisted by audio-visual media was effective for motivation and learning outcomes. Judging from the percentage of motivated students by $100 \%$, students completing attitude competence by $100 \%$, skill competence $91 \%$, knowledge competence $79 \%$, and the results of the t-test show that the learning outcomes of the experimental class knowledge competence are better than the control class from the value of $t=456>t$-table $=2.04$. The conclusion of this study is that PBL model assisted by audiovisual media is effective on student motivation and learning outcomes.

\section{Conclusion}

Through the collaboration of three discussion instruments with the assignment of power point learning media products, a cooperative learning model is formed that is able to increase student activity and learning outcomes. Both of these things continue to increase on the subject of Plantae. The completeness of learning outcomes achieved by class X MIPA1 students on the subject of Plantae from initial conditions to action in final conditions (cycle II) is increased by $54.55 \%$. 


\section{References}

Anderson, R. D. (2013). Inquiry as an organizing theme for science curricula. In Handbook of research on science education (pp. 821-844). Routledge.

Ariwidodo, E. (2020). Penerapan Bioteknologi Versus Lingkungan Hidup: Perspektif Filsafat Lingkungan (Vol. 221). Duta Media Publishing.

Fadillah, E. N. (2017). Pengembangan instrumen penilaian untuk mengukur keterampilan proses sains siswa SMA. Didaktika Biologi: Jurnal Penelitian Pendidikan Biologi, 1(2), 123-134.

Fitriah, E. (2016). Implementasi bioentrepreneurship pada pembelajaran biologi untuk meningkatkan life skills dan minat wirausaha siswa madrasah aliyah berbasis pesantren di Cirebon. Scientiae Educatia: Jurnal Pendidikan Sains, 2(1), 1-18.

Grobman, H. (2018). Evaluation in the biological sciences curriculum study 1958-65. In The role of evaluators in curriculum development (pp. 23-48). Routledge.

Mayer, R. E., \& Anderson, R. B. (2010). The instructive animations: Helping students build connections between words and pictures in multimedia learning. Journal of Educational Psychology, 84, 444-452.

Mousavi, S., Low, R., \& Sweller, J. (2010). Reducing cognitive load by mixing auditory and visual presentation modes. Journal of Educational Psychology, 87, 319-334.

Muhidin, S.A., \& Abdurahman, M. (2011). Analisis Korelasi, Regresi dan Jalur dalam penelitian. Bandung: Pustaka Setia.

Novitasari, R., Anggraito, Y. U., \& Ngabekti, S. (2015). Efektivitas Model Problem Based Learning Berbantuan Media Audio-Visual Terhadap Motivasi Dan Hasil Belajar Siswa Pada Materi Sistem Ekskresi. Journal of Biology Education, 4(3).

Purwanto. (2010). Metodologi Penelitian Kuantitatif. Yogyakarta: Pustaka Pelajar.

Sabri, T. (2013). Metode Demonstrasi Meningkatkan Aktivitas Siswa Pembelajaran IPA Kelas IV SDN 07 Sungai Soga Bengkayang. Jurnal Pendidikan dan Pembelajaran Khatulistiwa, 2(3).

Santoso, A. B., Alimah, S., \& Utami, N. R. (2017). Biological Science Curriculum Study 5e Instructional Model dengan Pendekatan Jelajah Alam Sekitar terhadap Kemampuan Literasi Sains. Journal of Biology Education, 6(2), 173-186.

Sudjana, N. (2010). Penilaian Hasil Proses Belajar Mengajar. Bandung: PT Remaja Rosdakarya.

Tammu, R. M. (2018). Keterkaitan metode dan media bervariasi dengan minat siswa dalam pembelajaran biologi tingkat SMP. JP (Jurnal Pendidikan): Teori dan Praktik, 2(2), 134142. 